\title{
Openness and the Effectiveness of Monetary Policy: A Cross-country Analysis
}

\section{Hakan Berument , Nazli Konac \& Ozge Senay}

To cite this article: Hakan Berument , Nazli Konac \& Ozge Senay (2007) Openness and the Effectiveness of Monetary Policy: A Cross-country Analysis, International Economic Journal, 21:4, 577-591, DOI: 10.1080/10168730701699018

To link to this article: https://doi.org/10.1080/10168730701699018

曲 Published online: 22 Nov 2007.

Submit your article to this journal $₫$

山 Article views: 79 


\title{
Openness and the Effectiveness of Monetary Policy: A Cross-country Analysis
}

\author{
HAKAN BERUMENT*, NAZLI KONAC** \& OZGE SENAY ${ }^{\dagger}$ \\ *Department of Economics, Bilkent University, Ankara, Turkey; ${ }^{* *}$ Citibank Inc., Istanbul, \\ Turkey; ${ }^{\dagger}$ Department of Economics, Middle East Technical University, Ankara, Turkey
}

\begin{abstract}
This paper evaluates the relationship between a country's openness to trade and the effectiveness of monetary policy in changing output growth and inflation in 29 different countries. Using quarterly data from the 1957-2003 period, empirical estimates based on individual country specifications show that the direction, significance and nature of the relationship between openness and the effectiveness of monetary policy on output growth as well as inflation vary considerably across countries.
\end{abstract}

KEY WORDS: Openness, monetary policy

JEL CLASSIFICATIONS: E52; F41

\section{Introduction}

This paper estimates the relationship between economic openness and the effectiveness of monetary policy on output growth and inflation. Theory suggests that monetary policy affects the economic performance of countries through several different channels and the relative importance of these channels depends on the degree of openness of the economy. In closed economies, monetary policy influences the economy mainly through changes in the relative cost of borrowing and balance sheet effects. Hence, monetary impulses are primarily transmitted into the economy via their effect on consumption and investment demand. In

Correspondence Address: Hakan Berument, Department of Economics, Bilkent University, Ankara, 06800, Turkey. Email: berument@bilkent.edu.tr 
open economies however, the transmission of monetary policy is more complicated and takes the form of a number of different channels, which operate through both the demand and supply side of the economy.

The demand channel, through which openness affects economic performance, operates through relative changes in the demand for domestically and foreign produced traded goods due to changes in the real terms of trade following the exchange rate response to monetary policy changes. ${ }^{1}$ The exact magnitude of this demand channel effect depends on the extent of the expenditure switching between domestic and foreign tradable goods. In turn, the strength of the expenditure switching effect depends on the elasticity of substitution between domestic and foreign tradable goods. ${ }^{2}$ The share of tradable goods in total consumption and production is also an important factor in determining the demand effects of monetary policy. In relatively more open countries, this share is higher so the demand effects of a depreciation of the domestic currency are stronger.

The impact of openness on the supply-side effects of monetary policy depends mainly on the way the exchange rate influences input prices, inflationary expectations and wage formation. For example, a depreciation of the exchange rate following a domestic monetary expansion leads to higher input prices, higher prices for imported consumer goods and higher wage demands. In relatively more open economies these supply-side mechanisms reduce the impact of monetary policy on output and increase the impact of monetary policy on consumer prices. $^{3}$

An important strand of the recent literature analyzes the implications of openness for the equilibrium inflation rate resulting from discretionary monetary policy. Rogoff (1985) and Romer (1993) argue that the more open the economy the smaller will be the inflationary bias of discretionary monetary policy. This is because (as described above) in more open economies a monetary expansion tends to have a stronger effect on prices and a weaker effect on output. The short-term benefits of unanticipated monetary expansion therefore fall as the degree of openness increases. A discretionary monetary authority therefore has a lower incentive to cause a monetary expansion in a very open economy. Lane (1997), however, argues that this applies only to large countries where monetary policy can affect the terms of trade. ${ }^{4}$ In Lane's model, a surprise inflation only increases production in the non-traded sector. The

\footnotetext{
${ }^{1}$ As with many aspects of the monetary transmission mechanism, the impact of monetary policy on the real terms of trade depends on the presence of rigidities in nominal prices or wages (for instance caused by contracts or menu costs). In addition, the extent of pass-through from exchange rate changes to prices also has an important impact on the power of monetary policy to affect the real terms of trade. If producers set prices in terms of the currency of the buyer there will be no pass-through and the real terms of trade will not change in response to a monetary policy shock (see Devereux \& Engel, 2003).

${ }^{2}$ See Sutherland (2006).

${ }^{3}$ See Bryant et al. (1998) and Karras (1999a, 1999b, 2001) for detailed expositions of this relationship.

${ }^{4}$ Large economies tend to face a less elastic demand for their exports and therefore have more power to affect the real terms of trade. Small economies tend to face very elastic demand for their tradable goods and therefore act as price takers in export markets.
} 
share of non-tradables in total production is smaller in more open economies so an expansion in non-tradables output does not provide a strong incentive for the monetary authority to introduce surprise inflation. Hence, Lane (1997) also reaches the conclusion that inflationary bias is weaker in open economies. $^{5}$

The theoretical literature thus suggests a number of important reasons to expect the impact of monetary policy to depend on the degree of openness. The current paper is an empirical investigation of the relationship between economic openness and the effectiveness of monetary policy on inflation and output growth. The main objective is to analyze the effects of openness across a wide range of countries using country-by-country estimations. We make use of quarterly data from 1957:2 to 2003:4 belonging to a group of 29 countries. ${ }^{6}$ Our results show that the degree of openness of a country carries different implications for the effectiveness of monetary policy on both output growth and the inflation rate among the sample used. A number of different specifications, including those using alternative definitions of money aggregates and the price level, alternative lag lengths, sample periods and exchange rate regimes all support the diversity of the results. That is, the significance, the nature and the direction of the relationship between the degree of openness and the effectiveness of monetary policy on output growth and inflation respectively, are found to differ widely across countries under all the different specifications estimated. This may suggest that the relationship between the degree of openness and the effectiveness of monetary policy depends upon other factors, which are discussed below.

Karras (1999a, 2001) also analyzes the relationship between openness and the effectiveness of monetary policy. Karras (1999a, 2001) carries out panel data analyses of different groups of countries and finds that for a panel of 38 countries (Karras, 1999a) and of eight countries (Karras, 2001), a negative relationship exists between openness and the effectiveness of monetary policy on output growth and a positive relationship between openness and the effect of monetary policy on inflation. Note that Karras focuses on panel estimation while we focus on country-by-country estimation.

The diverse results highlighted in this paper imply that the effectiveness of monetary policy may depend on the different characteristics of each country. Real differences in exchange rate regimes, the degree of independence of central banks, the country's exposure to international financial crises, terms-of-trade shocks, different monetary policymaking and the degree of capital controls could all potentially affect the transmission mechanism of monetary policy and thus have an impact on the relationship between openness and monetary policy effectiveness.

The paper proceeds as follows: the next section provides a description of the empirical methodology and the data used, while the subsequent after presents the empirical results. The fourth section presents a discussion of the results and the fifth section concludes.

\footnotetext{
${ }^{5}$ For further extensions of this strand of the literature see Temple (2002) and Wu \& Lin (2006).

${ }^{6}$ The sample range differs for some countries depending on data availability, see Table 1 for details.
} 


\section{Empirical Methodology and Data}

Three specifications based on the models of Karras (1999a, 2001) are used to evaluate the importance of each country's openness to trade on the effectiveness of monetary policy in that country. The equation that measures the effect of openness on the relationship between money growth and output growth, takes the following form:

$$
\begin{aligned}
\Delta y_{t}= & \beta_{0}+\sum_{i=1}^{3} \beta_{1 i} D_{i t}+\sum_{i=1}^{n} \beta_{2 i} \Delta y_{t-i}+\sum_{i=0}^{n} \beta_{3 i} \Delta m_{t-i}+\sum_{i=0}^{n} \beta_{4 i} \Delta O I L_{t-i}^{r} \\
& +\sum_{i=0}^{n} \beta_{5 i}\left(\text { open }_{t-i} \Delta m_{t-i}\right)+u_{t}
\end{aligned}
$$

where, $\Delta y_{t}$ is the growth rate of output, $\Delta m_{t}$ is the money growth rate, $\Delta O I L_{t}^{r}$ is the growth rate of the real price of oil, ${ }^{7}$ the variable open ${ }_{t}$ is the openness measure where openness is proxied by using the ratio of the sum of exports and imports to GDP and is defined as open $t=\left[\left(E X_{t}+I M_{t}\right) / G D P_{t}\right], D_{i t}$ are seasonal dummies included to account for seasonality and $u_{t}$ is the independent and identically distributed error term at time $t$. The $\beta$ s are the parameters to be estimated. In particular, $\beta_{5 i}$ is the set of parameters of interest that measure the effectiveness of monetary policy under different degrees of openness. ${ }^{8} n$ represents the lag length of each variable. The same number of lags was used for every variable in each country considered. Bayesian information criteria indicated the optimum lag length to be always three or less. Given that quarterly data were used, lag lengths were chosen to be four in the benchmark analysis.9

The equation used to capture the effect of openness on the money growth and inflation relationship for each country is specified as:

$$
\begin{aligned}
\Delta p_{t}= & \alpha_{0}+\sum_{i=1}^{3} \alpha_{1 i} D_{i t}+\sum_{i=1}^{n} \alpha_{2 i} \Delta p_{t-i}+\sum_{i=0}^{n} \alpha_{3 i} \Delta m_{t-i}+\sum_{i=0}^{n} \alpha_{4 i} \Delta \text { OIL }_{t-i} \\
& +\sum_{i=0}^{n} \alpha_{5 i}\left(\text { open }_{t-i} \Delta m_{t-i}\right)+\varepsilon_{t}
\end{aligned}
$$

\footnotetext{
${ }^{7}$ Oil prices are deflated using the GDP deflator of the USA.

${ }^{8}$ In order to assess the effectiveness of monetary policy on growth, we took the interactive term between opent-i and $\Delta m_{t-i}$ rather than opent and $\Delta m_{t-i}$ as in Karras (1999a, 2001). Using the interactive term between open $n_{t}$ and $\Delta m_{t-i}$ and carrying out the benchmark exercises below led to very similar results which are available on request.

${ }^{9}$ Alternatively, the number of lags can be varied across countries and/or across variables in order to decrease the number of parameters to be estimated and optimum lag lengths can be found by using other statistical criteria (such as AIC and final prediction error criteria). However, varying lag lengths could potentially prove to be quite problematical and lead to relatively incomparable results. This is because the lag length selected could change depending on the statistical criteria and the sample selection used. Therefore, the inference gathered from these estimates could also be subject to change. In order to avoid these problems, the same length lag was used for every variable in each country considered. However, to the test robustness of the benchmark analysis, all the exercises below were also carried out with alternative lag lengths of 2 and 8 , the results of which are discussed below.
} 
where $\Delta p_{t}$ s denote the inflation rate and $\Delta O I L_{t}$ is the growth rate of nominal oil prices, $\varepsilon_{t}$ is the independent and identically distributed error term at time $t$ and the $\alpha$ s are the sets of parameters to be estimated. In particular, $\alpha_{5 i}$ will show the effectiveness of monetary policy on the rate of inflation. The rest of the variables are as defined in equation (1).

A third equation is also used to capture the effect of openness on output growth and the effectiveness of monetary policy. In this equation, rather than using actual money growth (as is done in equation (1)), the unanticipated part of the money (i.e. money shocks or 'money innovations') - namely the residuals of the money equation - is used to measure the effects of money growth and output growth. The reason for writing the output growth equation in terms of money-supply shocks, as in Karras (1999b, 2001), is to address the usual criticism based on the endogeniety of the money supply. In order to address this problem, superconsistent estimates of money supply shocks are used to eliminate the endogeniety of money supply shocks. Therefore, we model the money supply process in levels rather than in terms of its growth rate. In order to extract money-supply shocks, the money supply process is assumed to take the following specification:

$$
m_{t}=\delta_{0}+\sum_{i=1}^{3} \delta_{1 i} D_{i t}+\sum_{i=1}^{n} \delta_{2 i} m_{t-i}+\sum_{i=1}^{n} \delta_{3 i} y_{t-i}+\sum_{i=0}^{n} \delta_{4 i} p_{t-i}+w_{t}
$$

The residual term of the money supply specification $\left(w_{t}\right)$ is taken to be the unanticipated part of money supply, i.e. money-supply shocks. Note that in equation (3), variables are written as levels into the money specification. If these variables are cointegrated, the estimated parameters are superconsistent (see Engle \& Granger, 1987) and are taken as the unanticipated part of money .

Using the money-supply shocks obtained from equation (3), we estimate the following equation in order to capture the effect of openness on output growth and the effectiveness of monetary policy:

$$
\begin{aligned}
\Delta y_{t}= & \varphi_{0}+\sum_{i=1}^{3} \varphi_{1 i} D_{i t}+\sum_{i=1}^{n} \varphi_{2 i} \Delta y_{t-i}+\sum_{i=0}^{n} \varphi_{3 i} w_{t-i}+\sum_{i=0}^{n} \varphi_{4 i} \Delta O I L_{t-i}^{r} \\
& +\sum_{i=0}^{n} \varphi_{5 i}\left(\text { open }_{t-i} w_{t-i}\right)+v_{t}
\end{aligned}
$$

Here, the $\phi$ s are the parameters to be estimated. In particular, $\phi_{5 i}$ is the set of parameters of interest that measures the effectiveness of monetary policy under different degrees of openness.

In all equations, the attention is mainly on the interactive terms as they are the terms that directly reflect the effect of openness on the money-output and moneyprice relationships in order to capture the effects of openness on the effectiveness of monetary policy.

The data used in the country-specific regressions are gathered from the International Monetary Fund's International Financial Statistics CD-ROM (2004). ${ }^{10}$

\footnotetext{
${ }^{10}$ The detailed description of the data, definition of the variables used and sources for each country's data are available from the authors upon request.
} 
Quarterly data from 1957:2 to 2003:4 are used (this range differs for some countries as dictated by data availability). To gather the estimates, the growth rate of money is found by using the M1 series in all countries, except for the UK where M2 was used. For some Euro-area countries (Belgium, Finland, Italy and the Netherlands) the M1 series were constructed by the summation of the currency in circulation and the demand deposits in the National Residency Banking Survey found in the IMF's International Financial Statistics (2004). In the price equation, $\Delta p$ is measured by the logarithmic first difference of the consumer price index (CPI). The real oil price index is constructed by dividing the US dollar oil price by the United States' GDP deflator. Openness is proxied by using the ratio of the sum of exports and imports to GDP. ${ }^{11}$

Table 1 provides a list of the 29 countries and presents the sample periods of the data set for each country, ${ }^{12}$ values of the country sample means for output growth, inflation, money growth and the openness measure. The second, third and fourth columns of Table 1 show that output, inflation and money growth all vary substantially across the countries considered. The average (quarterly) real growth rate ranges from $0.33 \%$ in Germany to $1.97 \%$ in Korea (South), while the average rate of inflation has ranged from $0.62 \%$ in Denmark to $30.15 \%$ in Peru. As for the average money growth rate, this is seen to range from $1.21 \%$ in Belgium to $18.44 \%$ in Peru.

The final column of Table 1 provides the sample means of the sum of exports and imports as a fraction of GDP, namely the measure of openness. Table 1 shows that the degree of openness varies substantially across all the countries considered. It ranges from a minimum of $16.6 \%$ in the United States to a maximum of $192.8 \%$ in Malaysia. The sheer size of this range and difference suggests that the effectiveness of monetary policies is expected to lead to very diverse output and price effects across the 29 countries considered.

\section{Empirical Results}

Table 2 Panel A reports the estimates of the sums of the interactive openness terms and Panel B provides the summary and diagnostic statistics. Each column of Panel A presents the total effect of the interactive money-openness variable plus its lags on output growth (column 1), inflation (column 2) where the growth rate of money is used and output growth where money-supply shocks are used (column 3). This corresponds to $\sum_{i=0}^{n} \beta_{5 i}$ in the output growth equation with money (equation (1)), $\sum_{i=0}^{n} \alpha_{5 i}$ in the inflation equation (equation (2)) and

\footnotetext{
${ }^{11}$ Other measures of openness, such as the degree of capital mobility, the effective rate of protection, the degree of equalization of interest rates across countries, the extent of pricing-to-market behavior by firms, may also be used as proxies. However, given the number of countries analysed, the measure used in this paper was thought to represent the most relevant and readily available openness variable with respect to measuring the effectiveness of monetary policy .

${ }^{12}$ It is evident that data availability differs across countries. Given that the main objective of this paper is to evaluate the effectiveness of monetary policy in a wide range of countries, we chose to keep the number of countries analyzed as large as possible. Although this led to degrees of freedom limitations for a few of the 29 countries, it is believed that estimations of these countries still provide relevant information regarding the aim of the paper.
} 
Table 1. Descriptive statistics

\begin{tabular}{|c|c|c|c|c|c|}
\hline Country & Time Span & $\frac{\text { Growth }}{\Delta y}$ & Inflation & $\frac{\text { Money }}{\Delta m}$ & {$\left[\frac{\text { Openness }}{(E X+I M)}\right.$} \\
\hline 1. Argentina & 1993:02-2003:04 & $0.493 \%$ & $1.113 \%$ & $3.171 \%$ & 24.42 \\
\hline 2. Australia & 1959:04-2002:01 & 0.910 & 1.387 & 2.301 & 32.62 \\
\hline 3. Austria & 1969:04-1997:04 & 0.687 & 1.059 & 1.684 & 71.55 \\
\hline 4. Belgium & 1980:02-1998:03 & 0.455 & 0.863 & 1.214 & 135.28 \\
\hline 5. Canada & 1957:02-2003:03 & 0.866 & 1.059 & 2.178 & 51.76 \\
\hline 6. Czech Republic & 1993:02-2003:04 & 0.707 & 1.419 & 3.951 & 123.44 \\
\hline 7. Denmark & $1987: 02-2003: 04$ & 0.576 & 0.624 & 1.558 & 70.4 \\
\hline 8. Ecuador & 1991:02-2002:02 & 0.538 & 8.772 & 2.034 & 59.59 \\
\hline 9. Finland & 1970:02-1998:04 & 0.747 & 1.645 & 3.699 & 56.74 \\
\hline 10. France & 1978:01-1998:04 & 0.494 & 1.255 & 1.425 & 44.54 \\
\hline 11. Germany & 1991:02-1998:04 & 0.326 & 0.646 & 1.846 & 50.29 \\
\hline 12. Italy & 1962:02-1998:04 & 1.040 & 1.995 & 3.032 & 38.85 \\
\hline 13. Japan & 1957:02-2003:01 & 1.314 & 0.958 & 2.674 & 21.08 \\
\hline 14. Korea (South) & 1970:02-2003:04 & 1.973 & 2.078 & 4.156 & 65.83 \\
\hline 15. Malaysia & 1991:02-2003:04 & 1.578 & 0.723 & 2.754 & 192.75 \\
\hline 16. Mexico & 1981:02-2003:04 & 0.573 & 7.913 & 8.021 & 42.1 \\
\hline 17. Netherlands & 1977:02-1997:04 & 0.573 & 0.736 & 1.649 & 111.67 \\
\hline 18. New Zealand & 1987:03-2003:04 & 0.640 & 0.676 & 2.213 & 58.66 \\
\hline 19. Norway & $1961: 02-2003: 03$ & 0.957 & 1.346 & 2.588 & 77.23 \\
\hline 20. Peru & 1979:02-2003:03 & 0.546 & 30.151 & 18.438 & 32.42 \\
\hline 21. Philippines & 1981:01-2003:04 & 0.739 & 2.372 & 3.411 & 71.69 \\
\hline 22. Portugal & 1980:01-1998:04 & 0.649 & 2.810 & 3.533 & 65.07 \\
\hline 23. South Africa & 1965:02-2003:04 & 0.645 & 2.357 & 3.586 & 50.88 \\
\hline 24. Spain & 1970:02-1998:04 & 0.721 & 2.357 & 3.164 & 36.8 \\
\hline 25. Sweden & 1980:02-2000:04 & 0.569 & 1.221 & 1.418 & 66.78 \\
\hline 26. Switzerland & $1970: 02-2003: 03$ & 0.357 & 0.789 & 1.389 & 68.32 \\
\hline 27. Turkey & $1987: 02-2003: 04$ & 1.266 & 13.493 & 12.612 & 45.93 \\
\hline 28. United Kingdom & 1957:02-2003:04 & 0.614 & 1.490 & 2.659 & 49.38 \\
\hline 29. United States & 1957:02-2003:04 & 0.817 & 1.022 & 1.351 & 16.62 \\
\hline
\end{tabular}

Notes: $\Delta y$ is the growth rate of real GDP, $\Delta p$ is the inflation rate, $\Delta m$ is the growth rate of money and open $n_{x m}$ is the sum of exports and imports as a fraction of GDP. All the data are gathered from IMF-IFS CD-ROM 2004.

$\sum_{i=0}^{n} \varphi_{5 i}$ in the output growth equation with money-supply shocks (equation (4)) respectively. In other words, the effectiveness of monetary policy on output growth with respect to higher openness captured by the estimates of the $\beta_{5 i} \mathrm{~s}$, the effectiveness of monetary policy on inflation with respect to higher openness represented by the estimates of $\alpha_{5 i}$ s and the effectiveness of monetary policy, defined as money-supply shocks, on output growth with respect to higher openness captured by the estimates of $\varphi_{5 i} \mathrm{~s}$ are all reported. Theory suggests that the estimated $\beta_{5 i}$ s (the coefficients of the openness terms) are expected to be negative, to indicate the declining effects of money on output with greater openness, the estimated $\alpha_{5 i}$ s must be positive to indicate that prices increase with the increasing level of openness in order to be consistent with expectations regarding the policy choice of the monetary authority .

Table 2 Panel A reports the estimates of the sums of the interactive openness terms where the standard errors are calculated by using robust standard errors. The first column in Table 2 Panel A shows the sum of the estimated interactive money-openness coefficient for each country. Hence, the first column gives a 
Table 2. The impact of openness on the effectiveness of monetary policy

\begin{tabular}{|c|c|c|c|c|c|c|c|c|}
\hline \multicolumn{4}{|c|}{ Panel A: Coefficient Estimates } & \multicolumn{5}{|c|}{ Panel B: Diagnostic Statistics } \\
\hline Country & Growth $M$ & Inflation $M$ & $\begin{array}{l}\text { Growth } \\
\text { M shocks }\end{array}$ & & Growth $M$ & Inflation $M$ & $\begin{array}{l}\text { Growth } \\
\text { M shocks }\end{array}$ & $\begin{array}{c}\text { D-F } \\
\text { Statistic }\end{array}$ \\
\hline 1. Argentina & $\begin{array}{c}-2.041 \\
(0.209)\end{array}$ & $\begin{array}{l}3.228^{* * *} \\
(0.001)\end{array}$ & $\begin{array}{r}-1.846 \\
(0.602)\end{array}$ & $\begin{array}{l}R^{2} \\
\text { L-B Q Stat }\end{array}$ & $\begin{array}{c}0.744 \\
(0.946)\end{array}$ & $\begin{array}{c}0.890 \\
(0.072)^{*}\end{array}$ & $\begin{array}{c}0.700 \\
(0.290)\end{array}$ & $-6.275^{* * *}$ \\
\hline 2. Australia & $\begin{array}{c}-0.530 \\
(0.398)\end{array}$ & $\begin{array}{c}-0.427^{* *} \\
(0.027)\end{array}$ & $\begin{array}{c}-1.528 \\
(0.380)\end{array}$ & $\begin{array}{l}R^{2} \\
\text { L-B Q Stat }\end{array}$ & $\begin{array}{c}0.217 \\
(0.186)\end{array}$ & $\begin{array}{c}0.938 \\
(0.513)\end{array}$ & $\begin{array}{c}0.231 \\
(0.176)\end{array}$ & $-12.925^{* * *}$ \\
\hline 3. Austria & $\begin{array}{c}-1.823^{* *} \\
(0.028)\end{array}$ & $\begin{array}{c}-0.327 \\
(0.119)\end{array}$ & $\begin{array}{c}-5.060^{* * *} \\
(0.009)\end{array}$ & $\begin{array}{l}R^{2} \\
\text { L-B Q Stat }\end{array}$ & $\begin{array}{c}0.310 \\
(0.490)\end{array}$ & $\begin{array}{l}0.919 \\
(0.032)^{* *}\end{array}$ & $\begin{array}{c}0.343 \\
(0.373)\end{array}$ & $-9.991^{* * *}$ \\
\hline 4. Belgium & $\begin{array}{c}0.271 \\
(0.821)\end{array}$ & $\begin{array}{c}-0.025 \\
(0.604)\end{array}$ & $\begin{array}{c}-1.137 \\
(0.670)\end{array}$ & $\begin{array}{l}R^{2} \\
\text { L-B Q Stat }\end{array}$ & $\begin{array}{c}0.339 \\
(0.899)\end{array}$ & $\begin{array}{c}0.997 \\
(0.206)\end{array}$ & $\begin{array}{c}0.300 \\
(0.709)\end{array}$ & $-8.388^{* * *}$ \\
\hline 5. Canada & $\begin{array}{c}-0.209 \\
(0.339)\end{array}$ & $\begin{array}{c}-0.017 \\
(0.678)\end{array}$ & $\begin{array}{c}0.146 \\
(0.773)\end{array}$ & $\begin{array}{l}R^{2} \\
\text { L-B Q Stat }\end{array}$ & $\begin{array}{c}0.144 \\
(0.931)\end{array}$ & $\begin{array}{c}0.945 \\
(0.550)\end{array}$ & $\begin{array}{c}0.126 \\
(0.980)\end{array}$ & $-13.627^{* * *}$ \\
\hline 6. Czech Republic & $\begin{array}{c}-1.531^{* *} \\
(0.030)\end{array}$ & $\begin{array}{c}-0.026 \\
(0.650)\end{array}$ & $\begin{array}{c}-0.986 \\
(0.236)\end{array}$ & $\begin{array}{l}R^{2} \\
\text { L-B Q Stat }\end{array}$ & $\begin{array}{c}0.690 \\
(0.510)\end{array}$ & $\begin{array}{c}0.992 \\
(0.600)\end{array}$ & $\begin{array}{c}0.716 \\
(0.470)\end{array}$ & $-5.036^{* * *}$ \\
\hline 7. Denmark & $\begin{array}{c}-3.655^{* * *} \\
(0.008)\end{array}$ & $\begin{array}{c}-0.265^{* * *} \\
(0.006)\end{array}$ & $\begin{array}{c}0.266 \\
(0.912)\end{array}$ & $\begin{array}{l}R^{2} \\
\text { L-B Q Stat }\end{array}$ & $\begin{array}{c}0.425 \\
(0.106)\end{array}$ & $\begin{array}{c}0.951 \\
(0.989)\end{array}$ & $\begin{array}{c}0.315 \\
(0.195)\end{array}$ & $-7.172^{* * *}$ \\
\hline 8. Ecuador & $\begin{array}{c}0.817 \\
(0.426)\end{array}$ & $\begin{array}{l}1.515 \\
(0.184)\end{array}$ & $\begin{array}{l}0.504 \\
(0.845)\end{array}$ & $\begin{array}{l}R^{2} \\
\text { L-B Q Stat }\end{array}$ & $\begin{array}{c}0.551 \\
(0.957)\end{array}$ & $\begin{array}{c}0.895 \\
(0.578)\end{array}$ & $\begin{array}{c}0.619 \\
(0.661)\end{array}$ & $-6.697^{* * *}$ \\
\hline 9. Finland & $\begin{array}{c}0.843^{*} \\
(0.059)\end{array}$ & $\begin{array}{c}0.228 \\
(0.118)\end{array}$ & $\begin{array}{c}0.409 \\
0.409 \\
(0.350)\end{array}$ & L-B Q Stat & $\begin{array}{c}0.452 \\
(0.481)\end{array}$ & $\begin{array}{c}0.939 \\
(0.998)\end{array}$ & $\begin{array}{c}0.001) \\
0.441 \\
(0.708)\end{array}$ & $-10.636^{* * *}$ \\
\hline 10. France & $\begin{array}{c}-1.999 \\
(0.242)\end{array}$ & $\begin{array}{c}-2.845^{* * *} \\
(0.002)\end{array}$ & $\begin{array}{r}-5.496 \\
(0.212)\end{array}$ & $\begin{array}{l}R^{2} \\
\text { L-B Q Stat }\end{array}$ & $\begin{array}{c}0.427 \\
(0.899)\end{array}$ & $\begin{array}{c}0.953 \\
(0.111)\end{array}$ & $\begin{array}{c}0.480 \\
(0.819)\end{array}$ & $-8.467^{* * *}$ \\
\hline 11. Germany & $\begin{array}{l}3.507^{* *} \\
(0.039)\end{array}$ & $\begin{array}{c}0.452 \\
(0.443)\end{array}$ & $\begin{array}{r}-5.367 \\
(0.904)\end{array}$ & $\begin{array}{l}R^{2} \\
\text { L-B Q Stat }\end{array}$ & $\begin{array}{c}0.609 \\
(0.911)\end{array}$ & $\begin{array}{c}0.989 \\
(0.182)\end{array}$ & $\begin{array}{l}0.821 \\
(0.001)^{* * *}\end{array}$ & $-4.562^{* * *}$ \\
\hline 12. Italy & $\begin{array}{c}-2.432 \\
(0.253)\end{array}$ & $\begin{array}{l}0.635^{* *} \\
(0.011)\end{array}$ & $\begin{array}{c}-11.179^{* * *} \\
(0.000)\end{array}$ & $\begin{array}{l}R^{2} \\
\text { L-B Q Stat }\end{array}$ & $\begin{array}{c}0.140 \\
(0.771)\end{array}$ & $\begin{array}{c}0.943 \\
(0.325)\end{array}$ & $\begin{array}{c}0.388 \\
(0.607)\end{array}$ & $-12.250^{* * *}$ \\
\hline 13. Japan & $\begin{array}{c}-0.327 \\
(0.719)\end{array}$ & $\begin{array}{c}-0.023 \\
(0.957)\end{array}$ & $\begin{array}{c}-1.484 \\
(0.383)\end{array}$ & $\begin{array}{l}R^{2} \\
\text { L-B Q Stat }\end{array}$ & $\begin{array}{c}0.627 \\
(0.961)\end{array}$ & $\begin{array}{c}0.936 \\
(0.534)\end{array}$ & $\begin{array}{c}0.605 \\
(0.967)\end{array}$ & $-13.281^{* * *}$ \\
\hline 14. Korea (South) & $\begin{array}{c}0.027 \\
(0.766)\end{array}$ & $\begin{array}{c}-0.092 \\
(0.649)\end{array}$ & $\begin{array}{c}0.362 \\
(0.136)\end{array}$ & $\begin{array}{l}R^{2} \\
\text { L-B Q Stat }\end{array}$ & $\begin{array}{c}0.225 \\
(0.059)^{*}\end{array}$ & $\begin{array}{c}0.880 \\
(0.413)\end{array}$ & $\begin{array}{c}0.474 \\
(0.320)\end{array}$ & $-11.453^{* * *}$ \\
\hline 15. Malaysia & $\begin{array}{c}-0.233 \\
(0.573)\end{array}$ & $\begin{array}{c}-0.028 \\
(0.705)\end{array}$ & $\begin{array}{l}1.461^{*} \\
(0.080)\end{array}$ & $\begin{array}{l}R^{2} \\
\text { L-B Q Stat }\end{array}$ & $\begin{array}{c}0.601 \\
(0.413)\end{array}$ & $\begin{array}{c}0.787 \\
(0.703)\end{array}$ & $\begin{array}{c}0.584 \\
(0.654)\end{array}$ & $-6.906^{* * *}$ \\
\hline
\end{tabular}




\begin{tabular}{|c|c|c|c|c|c|c|c|c|}
\hline 16. Mexico & $\begin{array}{l}0.843^{* * *} \\
(0.005)\end{array}$ & $\begin{array}{r}-0.019 \\
(0.292)\end{array}$ & $\begin{array}{l}2.095^{* * * *} \\
(0.001)\end{array}$ & $\begin{array}{l}R^{2} \\
\text { L-B Q Stat }\end{array}$ & $\begin{array}{c}0.421 \\
(0.925)\end{array}$ & $\begin{array}{l}0.996 \\
(0.001)^{* * *}\end{array}$ & $\begin{array}{c}0.472 \\
(0.666)\end{array}$ & $-9.439^{* * *}$ \\
\hline 17. Netherlands & $\begin{array}{l}2.050^{* *} \\
(0.045)\end{array}$ & $\begin{array}{c}-0.103 \\
(0.177)\end{array}$ & $\begin{array}{l}1.834 \\
(0.309)\end{array}$ & $\begin{array}{l}R^{2} \\
\text { L-B Q Stat }\end{array}$ & $\begin{array}{c}0.265 \\
(0.819)\end{array}$ & $\begin{array}{l}0.989 \\
(0.004)^{* * *}\end{array}$ & $\begin{array}{c}0.253 \\
(0.148)\end{array}$ & $-8.752^{* * *}$ \\
\hline 18. New Zealand & $\begin{array}{c}0.405 \\
(0.668)\end{array}$ & $\begin{array}{c}-0.103 \\
(0.575)\end{array}$ & $\begin{array}{c}-1.442 \\
(0.586)\end{array}$ & $\begin{array}{l}R^{2} \\
\text { L-B Q Stat }\end{array}$ & $\begin{array}{c}0.348 \\
(0.679)\end{array}$ & $\begin{array}{c}0.836 \\
(0.709)\end{array}$ & $\begin{array}{c}0.463 \\
(0.634)\end{array}$ & $-8.464^{* * *}$ \\
\hline 19. Norway & $\begin{array}{l}1.255^{* *} \\
(0.023)\end{array}$ & $\begin{array}{l}0.217^{* *} \\
(0.014)\end{array}$ & $\begin{array}{c}1.798 \\
(0.199)\end{array}$ & $\begin{array}{l}R^{2} \\
\text { L-B Q Stat }\end{array}$ & $\begin{array}{c}0.127 \\
(0.633)\end{array}$ & $\begin{array}{c}0.950 \\
(0.977)\end{array}$ & $\begin{array}{c}0.113 \\
(0.474)\end{array}$ & $-12.160^{* * *}$ \\
\hline 20. Peru & $\begin{array}{l}1.630^{* * * *} \\
(0.007)\end{array}$ & $\begin{array}{c}-4.268^{* *} \\
(0.011)\end{array}$ & $\begin{array}{l}1.803 \\
(0.144)\end{array}$ & $\begin{array}{l}R^{2} \\
\text { L-B Q Stat }\end{array}$ & $\begin{array}{c}0.453 \\
(0.991)\end{array}$ & $\begin{array}{c}0.976 \\
(0.413)\end{array}$ & $\begin{array}{c}0.343 \\
(0.983)\end{array}$ & $-9.760^{* * *}$ \\
\hline 21. Philippines & $\begin{array}{c}-0.086 \\
(0.741)\end{array}$ & $\begin{array}{c}-0.046^{* * *} \\
(0.005)\end{array}$ & $\begin{array}{l}0.817^{* *} \\
(0.015)\end{array}$ & $\begin{array}{l}R^{2} \\
\text { L-B Q Stat }\end{array}$ & $\begin{array}{l}0.317 \\
(0.035)^{* *}\end{array}$ & $\begin{array}{c}0.976 \\
(0.755)\end{array}$ & $\begin{array}{l}0.418 \\
(0.067)^{*}\end{array}$ & $-9.069^{* * *}$ \\
\hline 22. Portugal & $\begin{array}{c}0.576 \\
(0.249)\end{array}$ & $\begin{array}{c}0.136 \\
(0.532)\end{array}$ & $\begin{array}{c}2.172 \\
(0.208)\end{array}$ & $\begin{array}{l}R^{2} \\
\text { L-B Q Stat }\end{array}$ & $\begin{array}{c}0.352 \\
(0.757)\end{array}$ & $\begin{array}{c}0.977 \\
(0.307)\end{array}$ & $\begin{array}{c}0.410 \\
(0.954)\end{array}$ & $-7.455^{* * *}$ \\
\hline 23. South Africa & $\begin{array}{l}0.711^{* *} \\
(0.044)\end{array}$ & $\begin{array}{c}0.117 \\
(0.143)\end{array}$ & $\begin{array}{c}-0.118 \\
(0.878)\end{array}$ & $\begin{array}{l}R^{2} \\
\text { L-B Q Stat }\end{array}$ & $\begin{array}{c}0.220 \\
(0.188)\end{array}$ & $\begin{array}{c}0.955 \\
(0.977)\end{array}$ & $\begin{array}{c}0.213 \\
(0.232)\end{array}$ & $-12.27^{* * *}$ \\
\hline 24. Spain & $\begin{array}{c}0.126 \\
(0.495)\end{array}$ & $\begin{array}{c}-0.293 \\
(0.278)\end{array}$ & $\begin{array}{c}-0.664 \\
(0.495)\end{array}$ & $\begin{array}{l}R^{2} \\
\text { L-B Q Stat }\end{array}$ & $\begin{array}{l}0.833 \\
(0.010)^{* * *}\end{array}$ & $\begin{array}{c}0.953 \\
(0.054)^{*}\end{array}$ & $\begin{array}{c}0.867 \\
(0.167)\end{array}$ & $-10.28^{* * *}$ \\
\hline 25. Sweden & $\begin{array}{c}0.957 \\
(0.401)\end{array}$ & $\begin{array}{c}0.153 \\
(0.604)\end{array}$ & $\begin{array}{l}2.383 \\
(0.133)\end{array}$ & $\begin{array}{l}R^{2} \\
\text { L-B Q Stat }\end{array}$ & $\begin{array}{c}0.162 \\
(0.228)\end{array}$ & $\begin{array}{c}0.976 \\
(1.000)\end{array}$ & $\begin{array}{c}0.248 \\
(0.163)\end{array}$ & $-7.919^{* * *}$ \\
\hline 26. Switzerland & $\begin{array}{c}-0.666 \\
(0.448)\end{array}$ & $\begin{array}{c}-0.146 \\
(0.345)\end{array}$ & $\begin{array}{c}-1.598 \\
(0.308)\end{array}$ & $\begin{array}{l}R^{2} \\
\text { L-B Q Stat }\end{array}$ & $\begin{array}{c}0.308 \\
(0.892)\end{array}$ & $\begin{array}{c}0.894 \\
(0.907)\end{array}$ & $\begin{array}{c}0.294 \\
(0.561)\end{array}$ & $-12.10^{* * *}$ \\
\hline 27. Turkey & $\begin{array}{c}-0.015 \\
(0.976)\end{array}$ & $\begin{array}{c}-0.386 \\
(0.209)\end{array}$ & $\begin{array}{c}-2.237 \\
(0.348)\end{array}$ & $\begin{array}{l}R^{2} \\
\text { L-B Q Stat }\end{array}$ & $\begin{array}{l}0.355 \\
(0.735)\end{array}$ & $\begin{array}{c}0.853 \\
(0.270)\end{array}$ & $\begin{array}{c}0.446 \\
(0.055)^{*}\end{array}$ & $-7.969^{* * *}$ \\
\hline 28. United Kingdom & $\begin{array}{c}-0.186 \\
(0.710)\end{array}$ & $\begin{array}{c}-0.046 \\
(0.832)\end{array}$ & $\begin{array}{c}-0.920 \\
(0.240)\end{array}$ & $\begin{array}{l}R^{2} \\
\text { L-B Q Stat }\end{array}$ & $\begin{array}{c}0.143 \\
(0.594)\end{array}$ & $\begin{array}{c}0.900 \\
(0.304)\end{array}$ & $\begin{array}{c}0.155 \\
(0.268)\end{array}$ & $-13.78^{* * *}$ \\
\hline 29. United States & $\begin{array}{r}-2.721^{*} \\
(0.055)\end{array}$ & $\begin{array}{c}-0.078 \\
(0.793)\end{array}$ & $\begin{array}{l}2.487 \\
(0.372)\end{array}$ & $\begin{array}{l}R^{2} \\
\text { L-B Q Stat }\end{array}$ & $\begin{array}{c}0.142 \\
(0.969)\end{array}$ & $\begin{array}{c}0.918 \\
(0.681)\end{array}$ & $\begin{array}{c}0.136 \\
(0.869)\end{array}$ & $-13.42^{* * *}$ \\
\hline
\end{tabular}

Significance levels ( $p$-values) are given in parentheses. Robust standard errors are used to calculate the standard errors. * significant at $10 \%$ level; ${ }^{* *}$ significant at $5 \%$ level and *** significant at $1 \%$ level. 
measure of the impact of openness on the effectiveness of monetary policy on output growth where the growth rate of money supply itself is used. The second column repeats the same exercise for the inflation rate. In this case, the sum of the estimated interactive coefficients in the inflation equation is used as a measure of the impact of openness on the effectiveness of monetary policy on the inflation rate. The third column gives another measure of the impact of openness on the effectiveness of monetary policy on output growth where money-supply shocks are used instead of the growth rate of money itself.

As can be seen from the first column of Table 2 Panel A, the growth effects of openness vary to a great extent among the countries in the sample. The findings show that for 14 countries (Belgium, Ecuador, Finland, Germany, Korea, Mexico, the Netherlands, New Zealand, Norway, Peru, Portugal, South Africa, Spain and Sweden), a higher degree of openness increases the effectiveness of monetary policy on output growth. However, only for eight of the countries (Finland, Germany, Mexico, the Netherlands, Norway, Peru, South Africa and the United States), can it be concluded that such a relationship is statistically significant. ${ }^{13}$ For the rest of the sample, the degree of openness is negatively related to the effectiveness of monetary policy on output growth. As for significance, the results show that out of the 15 countries with negative estimates, only four countries (Austria, the Czech Republic, Denmark and the United States) show a statistically significant relationship.

The second column in Table 2 Panel A presents estimation results pertaining to the inflation rate effects. Column 2 shows that nine countries exhibit a positive relationship between openness and the effectiveness of monetary policy on prices (Argentina, Ecuador, Finland, Germany, Italy, Norway, Portugal, South Africa and Sweden). Within the group, three (Argentina, Italy and Norway) have statistically significant estimates. The rest of the sample exhibits negative estimates, but only for five of the countries (Australia, Denmark, France, Peru and the Philippines) do we find a statistically significant relationship between prices and openness.

The third column in Table 2 Panel A gives the results of the impact of openness on the effectiveness of monetary policy on output growth where money-supply shocks are used. As can be seen from the third column of Table 2, the effects of openness on output growth using money-supply shocks varies among the countries in the sample. The findings show that for 14 countries (Canada, Denmark, Ecuador, Finland, Korea, Malaysia, Mexico, the Netherlands, Norway, Peru, Philippines, Portugal, Sweden and the United States), a higher degree of openness increases the effectiveness of monetary policy on output growth. However, only in three of the countries (Malaysia, Mexico and the Philippines) is the relationship statistically significant. For the rest of the sample, the degree of openness is negatively related to the effectiveness of monetary policy on output growth. As for significance, the results show that out of the 15 countries with negative estimates, only two countries (Austria and Italy) show a statistically significant relationship.

\footnotetext{
${ }^{13}$ The level of significance is at the $10 \%$ level unless otherwise mentioned.
} 
Now, let us compare the effectiveness of monetary policy on output growth using the two different measures of monetary policy used above - firstly money supply aggregates (column 1) and secondly money-supply shocks (column 3) (unanticipated money supply). It is found that in the cases where a statistically significant estimate between the monetary policy variable (measured by the monetary aggregate or money-supply shocks) and output growth exists, the sign of the relationship does not change. However, only for six countries (Denmark, Germany, Malaysia, Philippines, South Africa and the United States) does a statistically significant coefficient (in column 1 or 3 ) of monetary policy change signs and become statistically insignificant (in column 1 or 3 ).

At this point, it is also worth highlighting the results belonging to the European Union (EU) countries within the sample. Given the high degree of openness to trade amongst these countries, any strong convergence in the estimates is unable to be detected. The diversity of results within the whole sample also applies to the sub-sample of EU countries. Within these countries, seven (Belgium, France, Italy, Portugal, Spain, Sweden and the United Kingdom) do not show a statistically significant relationship between the output growth effects of monetary policy (where monetary policy is measured using monetary aggregates) and openness to trade. Whereas Austria, the Czech Republic and Denmark have a statistically significant negative relationship between the output growth performances of monetary policy and openness, Finland, Germany and the Netherlands display a positive relationship. When monetary policy is measured using money-supply shocks, only Austria and Italy show the presence of a statistically significant relationship between the effectiveness of monetary policy and openness to trade: both display a negative relationship. The effectiveness of monetary policy on inflation, on the other hand, is (statistically significantly) negatively related to openness in Denmark and France, contrary to the case in Italy where a (statistically significant) positive relationship is displayed. The degree of openness in the EU countries is relatively similar due to the common external tariff and trade regulations in place. However, results show that the EU countries exhibit diverse results. Hence, it can be stated that when the European Union sub-sample is closely examined, the general conclusion of this paper is reinforced: One is unable to make any general statements regarding the direction and the significance of the relationship between openness and the effectiveness of monetary policy .

Table 2 Panel B reports the summary and diagnostic statistics related to the estimates in Panel A. For each country and each specification, the $R^{2}$ and the $p$-values for the Ljung-Box Q statistics are provided. Regarding the Ljung-Box Q statistic for eight periods, out of a total of $87 \mathrm{Q}$ statistics (three for each of the 29 countries) only 11 are found to be statistically significant at the $10 \%$ level. Therefore, given that the analysis above uses robust standard errors, the inference gathered from Panel A can still be regarded as being valid. The final column in Table 2 Panel B reports the Dickey-Fuller (D-F) statistics for the residual term of the money supply specification $\left(w_{t}\right)$ in equation (3), i.e. the money supply equation. Given that the variables in equation (3) are to be estimated in levels, these variables should be cointegrated. Therefore, the last column in Table 2 Panel $\mathrm{B}$ reports the Dickey-Fuller unit root tests for the residual terms. All the D-F test statistics are found to be statistically significant at the $1 \%$ level. Thus, it can be 
claimed that the variables as used in equation (3) are indeed cointegrated and the estimates of the monetary policy shocks are superconsistent.

The fact that the results differ in their signs with respect to the impact of openness on the effectiveness of monetary policy on growth and inflation respectively is a solid enough indicator of the diversified nature of the sample. While some countries' growth performance under expansionary monetary policy is negatively affected by openness, some countries show a positive relationship. The same goes for inflation effects, showing that one cannot conclusively determine whether the inflationary effect of a monetary expansion increases or decreases with increased openness.

Given that the 29 countries in our sample have all experienced different exchange rate regimes and that a single country may have switched from one regime to another during our sample periods, it may be worthwhile to see whether the above diversity of results is still valid under different exchange rate regime periods. For this purpose, first, the above four equations were estimated separately for the post-1973 period as a general period of floating exchange rates, as carried out by Karras (1999b, 2001). Second, to take into account the regime switches occurring within each country over the sample period, the above four equations were estimated separately for only the floating exchange rate regime periods for each of the 29 countries within our total sample period. The exact periods of floating regimes experienced by each country was taken from Reinhart \& Rogoff (2002). Therefore, the system of equations (1) to (4) was estimated for the following sub-samples: $i$. for 29 countries for the post-1973 period of floating exchange rates and ii. for 24 countries' floating exchange rate regime periods occurring in the full sample period, 1957:2 - 2003:4. ${ }^{14}$ Results in each sub-sample show that, as was the case above, results differ in their signs and significance with respect to the impact of openness on the effectiveness of monetary policy on output growth and inflation respectively across countries. ${ }^{15}$ This shows, again, that one cannot conclusively determine whether the effectiveness of monetary policy on economic performance increases or decreases with higher openness.

As a simple test of the robustness of the above results, the system of equations (1) to (4) was estimated for the whole sample using different specifications of key variables such as money aggregates and price variables. First, the system of equations was estimated using the M2 series instead of the M1 series (as was used in the benchmark results) as the money aggregate. Second, $\Delta p$ was measured by the logarithmic first difference of the GDP deflator, instead of the CPI (as used in the benchmark results). Both sets of results were found to be consistent with the above findings. That is, results differed in their signs with respect to the impact of openness on the effectiveness of monetary policy on growth and inflation respectively across countries under different measures of money aggregates and the price level, pointing at the general robustness of the benchmark results.

Lastly, it was considered that the lag structure of the analysis, as it stands at four periods, may be subject to criticism in that it may take longer than a year

\footnotetext{
${ }^{14}$ Data availability restrictions prevented analyses of Austria, Belgium, Denmark, France and the Netherlands.

${ }^{15}$ The full set of results are not reported here due to space limitations but are available on request.
} 
for the effects of monetary policy to be fully absorbed by the economy. In order to account for this, the four equation system was estimated with eight lags for the full sample (i.e. repeating the benchmark analysis in Table 2 with eight lags) and under different sub-samples (post-1973), under floating exchange rate regime periods occurring between 1957:2 - 2003:4 for each country, and under different money (M2) and price level measures (GDP deflator) than those in the benchmark case above. The results show that the general conclusions reached under the benchmark estimations all hold true under each of the above variations. That is, the significance and nature of the relationship between openness and the effectiveness of monetary policy on inflation as well as output growth vary considerably across countries. ${ }^{16}$

\section{Discussion}

Given that the main objective of this paper is to analyze the effectiveness of monetary policy on the rate of inflation and output growth across a wide range of countries with different degrees of openness, this section will provide a general context in which to understand the findings of this paper.

The country-specific regressions in this paper reveal that it is difficult to make any conclusive general statements about the effects of openness to trade on the effectiveness of monetary policy. It is found that the effects of openness on the money growth-output and the money-inflation rate relationships vary to a great extent from country to country. The obvious conclusion that may be reached from this paper is that the direction and possibly the nature of the relationship between openness and monetary policy effectiveness are liable to considerable changes across countries. Moreover, in most of the countries analyzed, one is unable to obtain a significant relationship between the effects of openness on the effectiveness of monetary policy jointly on output and on prices.

A possible reason for the differences between the results of earlier studies and the results obtained in this paper may be related to differences in the methodologies used. It is important to consider Karras's (1999a, 2001) results, taking note that in both papers his results are obtained using a panel data analysis. The use of panel data techniques requires the estimation of a single parameter measuring the effectiveness of monetary policy on output growth and inflation. However, a country-by-country analysis allows the estimation of a different parameter for each country and may therefore allow for the reflection of greater diversity in the results.

While previous studies provide a useful context in which to understand the results of this paper, it is important to note that a major difference in the methods

\footnotetext{
${ }^{16}$ On the other hand, it could potentially be argued that a lag length of four is too high and that this could lower the efficiency of estimates and conceal changes in the effectiveness of monetary policy. However, the results show that even with a lag length of four, there are cases where the effectiveness of monetary policy is found to vary. Nevertheless, in order to test the robustness of our findings, all the exercises (full sample (benchmark) and post-1973 and floating rate regime periods sub-samples, under different money (M2) and price level measures (GDP deflator)) were carried out using a lag length of two. These sets of results were also found to be consistent with those using a lag length of four and eight.
} 
of analyzing the role of openness renders a direct comparison across these to be rather uninformative. For instance, this paper introduces a time varying openness measure to assess the effectiveness of monetary policy on output growth and inflation. This may prevent a direct comparison being made with panel estimation studies, which introduce time varying and cross-country variation of openness to evaluate the effectiveness of monetary policy. In other words, the country-bycountry estimations carried out in this paper only use the variation of openness within each country and not the variation among different countries, as in the panel estimations.

It is also important to comment on possible factors underlying the simple diversity in the effects of monetary policy on output and prices. The diverse results highlighted in this paper imply that the effectiveness of monetary policy also depends on the uniquely different characteristics and features of each country. The dispersion of results reflects real differences among the 29 countries analyzed. These differences include the diverse nature of the economic and monetary structures of the countries in the sample, differences in their monetary policy-making tools, the degree of central bank independence, differences in exchange rate regimes, capital account controls, wage setting procedures, the country's exposure to international financial crises, terms-of-trade shocks, as well as country-specific features in the workings of the monetary transmission mechanism. In addition to these real differences, country-specific idiosyncratic shocks may also explain the diversity in results.

\section{Conclusions}

This paper analyses the effectiveness of monetary policy on prices and output under different degrees of economic openness. It evaluates the effectiveness of monetary policy on inflation and output across a wide range of countries with different degrees of openness using a country-by-country analysis. We make use of quarterly data from 1957:2 to 2003:4 belonging to a group of 29 countries in order to examine the relationship between openness and the effectiveness of monetary policy on inflation and output growth. Empirical evidence shows that the degree of openness of a country carries different implications for the effectiveness of monetary policy on both output growth and inflation among the sample used. Using country-specific regressions, the paper finds diverse results amongst the sample of 29 countries analyzed. The significance and the direction of the relationship between the degree of openness and the effectiveness of monetary policy on output growth and inflation respectively are found to differ widely across countries. This suggests that the relationship between the degree of openness and the effectiveness of monetary policy depends upon other factors, such as the presence of real differences between the countries considered and country specific features in the workings of the monetary transmission mechanism.

\section{Acknowledgements}

We would like to thank an anonymous referee for helpful comments. 


\section{References}

Bryant, R., Henderson, D., Holtham, G. \& Symansky, S. (1998) Empirical Macroeconomics for Independent Economies (Washington DC: Brookings Institution).

Devereux, M.B. \& Engel, C. (2003) Monetary policy in an open economy revisited: price setting and exchange rate flexibility, Review of Economic Studies, 70, pp. 765-783.

Engle, R. \& Granger, C. (1987) Cointegration and error-correction: representation, estimation, and testing, Econometrica, 55, pp. 251-276.

International Monetary Fund (2004) International Financial Statistics CD-ROM, version 1.1.54.

Karras, G. (1999a) Openness and the effects of monetary policy, Journal of International Money and Finance, 18, pp. 13-26.

Karras, G. (1999b) Monetary policy and the exchange rate: the role of openness, International Economic Journal, 13 , pp. $75-88$.

Karras, G. (2001) Openness to trade and the potency of monetary policy: how strong is the relationship, Open Economies Review, 12, pp. 61-73.

Lane, P. (1997) Inflation in open economies, Journal of International Economics, 42, pp. 327-342.

Reinhart, C. \& Rogoff, K. (2002) The modern history of exchange rate arrangements: a reinterpretation. NBER Working Paper 8963.

Rogoff, K. (1985) Can international monetary policy be counterproductive? Journal of International Economics, 18, pp. 199-217.

Romer, D. (1993) Openness and inflation: theory and evidence, Quarterly Journal of Economics, 108, pp. 869-903.

Sutherland, A. (2006) The expenditure switching effect, welfare and monetary policy in a small open economy, Journal of Economic Dynamics and Control, 30, pp. 1159-1182.

Temple, J. (2002) Openness, inflation and the Phillips curve: a puzzle, Journal of Money, Credit and Banking, 34(2), pp. 450-468.

Wu, C.S. \& Lin, J. L. (2006) The relationship between openness and inflation in NIEs and G7, in: T. Ito \& A. Rose (eds) International Financial Issues Around the Pacific Rim, East Asia Seminar on Economics, Volume 17, NBER (forthcoming). 